TATA LOKA

Volume 20 Nomor 3, Agustus 2018, 232-249

(C) 2018 Biro PenERBit PlanOlogi UNDIP

P ISSN 0852-7458- E ISSN 2356-0266

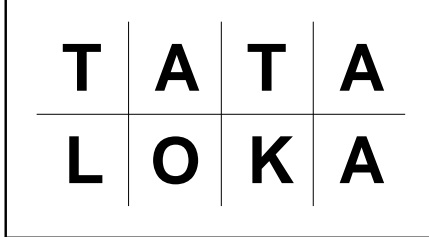

\title{
ADAPTASI MASYARAKAT BAJO TERHADAP PERUBAHAN LINGKUNGAN DI TELUK BALIKPAPAN
}

\author{
Adaptation of Bajo People toward Environmental Change \\ in Balikpapan Bay
}

\section{Ramli ${ }^{1}$, Endratno Budi Santosa ${ }^{2}$ and A. Nurul Hidayati ${ }^{3}$}

Diterima: 23 Februari 2018

Disetujui: 24 April 2018

\begin{abstract}
Penelitian ini bertujuan untuk mengetahui kapasitas masyarakat Bajo dalam menghadapi perubahan lingkungan (permukiman) dengan menghitung indikator kerentanan kapasitas adaptif. Analisis komparatif digunakan untuk mengetahui perbandingan kapasitas adaptasi, yang ditunjang dengan pendekatan kuantifikasi. Sebagai penjelas, juga digunakan indepth interview, dan pendekatan fish bone untuk mengetahui keterkaitan antar fakta yang ada. Penelitian dilakukan di permukiman Suku Bajo di Kelurahan Penajam, Kelurahan Jenebora, dan Kelurahan Pantai Lango, Penajam Paser Utara, Kalimantan Timur, dengan menggunakan sembilan variable utama penyusun kerentanan masyarakat terhadap perubahan lingkungan. Berdasarkan analisis, kondisi permukiman Bajo di lokasi penelitian telah mengalami perubahan karena adanya peningkatan populasi dan mempengaruhi keragaman ruang dan tempat tinggalnya. Meskipun memiliki kondisi kerentanan yang bervariasi, berdasarkan analisis menunjukkan bahwa masyarakat Penajam memiliki tingkat kapasitas adaptasi terhadap perubahan lingkungan lebih baik (ada pada level sedang), dibandingkan masyarakat di Jenebora dan Pantai Lango yang level adaptasinya lebih rendah.
\end{abstract}

Keywords: kerentanan, kapasitas adaptasi, masyarakat Bajo, perubahan lingkungan, Teluk Balikpapan

\begin{abstract}
This article trying to identify the Bajo people's adaptation capacity regarding environmental change through vulnerable capacity index calculation and comparative analyze as well. Using indepth interview and fish bone diagram approaching, this research trying to find out the connectivity between new spreading industry activities, environmental change, and how the people can adapt. We choosing of three Bajo people settlements, located around Balikpapan Bay as the cases study, and also using nine variables of vulnerable society. As the results, we can find if there were some significant physical-environment changes both on quality and quantity aspects. After calculating vulnerability index, it shows that level of adaptation capacity at Penajam village better than its on Jenebora and Pantai Lango village as well.
\end{abstract}

Keywords: vulnerability, adaptation capacity, Bajo society, environmental change, Balikpapan bay

\footnotetext{
1,2,3 Jurusan Perencanaan Wilayah dan Kota, Fakultas Teknik Sipil dan Perencanaan, Institut Teknologi Nasional Malang
} 


\section{PENDAHULUAN}

Indonesia merupaan negara kepulauan dengan sekitar 13 ribu pulau, dengan total luasan sekitar tujuh juta $\mathrm{Km}^{2}$. Tahun 2012, tercatat sekitar 230 juta penduduk Indonesia, yang terdiri atas seribu variasi etnis ataupun sub etnis dengan karakter budaya dan tradisi yang beraneka ragam (AMAN, 2012). Salah satu suku yang menarik adalah Suku Bajo, merupakan suku nomaden yang hidup di atas laut, sehingga disebut gipsi laut. Suku Bajo menggunakan bahasa Sama-Bajau, dan sejak ratusan tahun yang lalu sudah menyebar ke Negeri Sabah-Malaysia dan berbagai wilayah Indonesia.

Suku-suku di Kalimantan diperkirakan bermigrasi dari arah Utara (Filipina) pada zaman prasejarah. Suku Bajo merupakan gelombang terakhir migrasi dari arah Utara Kalimantan yang memasuki Pesisir Kalimantan Timur hingga Kalimantan Selatan dan menduduki pulau-pulau sekitarnya. Mereka datang lebih dahulu daripada kedatangan suku-suku dari rumpun Bugis yaitu suku Bugis, suku Makassar, dan suku Mandar. Orang Bajo dikenal sebagai orang yang mengembangkan suatu cara hidup yang unik dan bersifat maritim. Lingkungan hidup mereka begitu dekat dengan laut menyebabkan penghuni memanfaatkan laut bagi kelangsungan hidupnya serta mempunyai sikap statis, suka hidup di laut, kurang berinovasi, bersikap tertutup dan tidak mampu beradaptasi secara fisik geografis, sosial dan budaya dengan penduduk yang hidup di darat. Akibatnya Suku Bajo kurang terlibat didalam proses dan menikmati hasil pembangunan.

Lokasi tinggal masyarakat Bajo di Teluk Balikpapan dalam studi ini terdapat pada tiga lokasi yaitu : Kelurahan Penajam, Jenebora, dan, Kelurahan Pantai Lango. Masyarakat pesisir yang tersebar di Teluk Balikapapan mayoritas merupakan masyarakat yang berprofesi sebagai nelayan khususnya untuk masyarakat yang berada dalam lingkup wilayah Kabupaten Penajam. Kondisi berbeda di wilayah Pesisir Kota Balikpapan yang sangat jarang ditemukan nelayan, karena mayoritas masyarakat di tempat ini berprofesi sebagai penyedia jasa transportasi air, berupa perahu ferry, speed boat ataupun kelotok. Kelurahan Jenebora merupakan salah satu kelurahan yang hampir semua penduduknya tinggal di pesisir, sangat berbanding terbalik dengan daratannya yang luas namun tidak banyak penduduk yang tinggal di sana. Pantai Lango memiliki jarak yang tidak begitu jauh dari Kelurahan Jenebora, butuh waktu 10 menit dengan speed boat untuk sampai ke kelurahan ini. Hampir sama dengan Kelurahan Jenebora, penduduk Kelurahan Pantai Lango juga tinggal di pesisir yang menjorok ke laut.

Pada awalnya dalam masterplan Kawasan Industri Kariangau (KIK) yang diusulkan oleh KAPET SASAMBA Kaltim (Kawasan Pengelolaan Terpadu Samarinda Samboja dan Balikpapan) selaku konsultan di Pemerintahan Propinsi Kalimantan Timur, kawasan KIK direncanakan seluas 2.189 hektar (dari teluk Kariangau hingga Teluk Waru) pada tahun 2004. Namun pada kenyataannya, batas pembangunan di kawasan KIK yang hanya sampai di pelabuhan peti kemas, ternyata masih ditambah dua perusahaan pengolahan minyak sawit mentah yang saat ini salah satu pabrik bahkan telah membangun pabrik untuk pengemasan yang berada di Kawasan Pembangunan Jembatan Pulau Balang. Perusahaan tersebut yaitu PT. MBA dan PT. DKI. Kawasan tersebut berada di luar kawasan industri yang telah ditetapkan (Saturi, 2013). Gambar (1,2, dan 3) di bawah ini menunjukkan peta orientasi lokasi penelitian.

Keberadaan berbagai aktivitas baru termasuk industri sedikit banyak akan mempengaruhi secara fisik dan non fisik bagi lingkungan di sekitarnya. Apalagi ini berlaku pada sebuah masyarakat tradisional yang cenderung lambat dalam menerima perubahan, yang disebabkan gaya hidupnya yang cenderung tradisional dan mempertahankan warisan budaya-kebiasaan dari nenek moyangnya. Berkaitan dengan fenomena yang ada tersebut, beberapa masalah yang dijadikan fokus penelitian ini antara lain : Seperti apakah perubahan lingkungan yang mempengaruhi kehidupan masyarakat Bajo di Pesisir Teluk 
Balikpapan; Bagaimana tingkat kapasitas adaptasi bermukim masyarakat Bajo dalam menghadapi perubahan lingkungan yang tengah terjadi di lingkungan mereka, dalam kasus kali ini berlokasi di Teluk Balikpapan; dan Bagaimana perbandingan atau komparasi dari kapasitas adaptasi masyarakat Bajo pada tiga lokasi studi pemukiman Bajo, yaitu Kelurahan Pantai Lango, Jenebora, dan Kelurahan Penajam

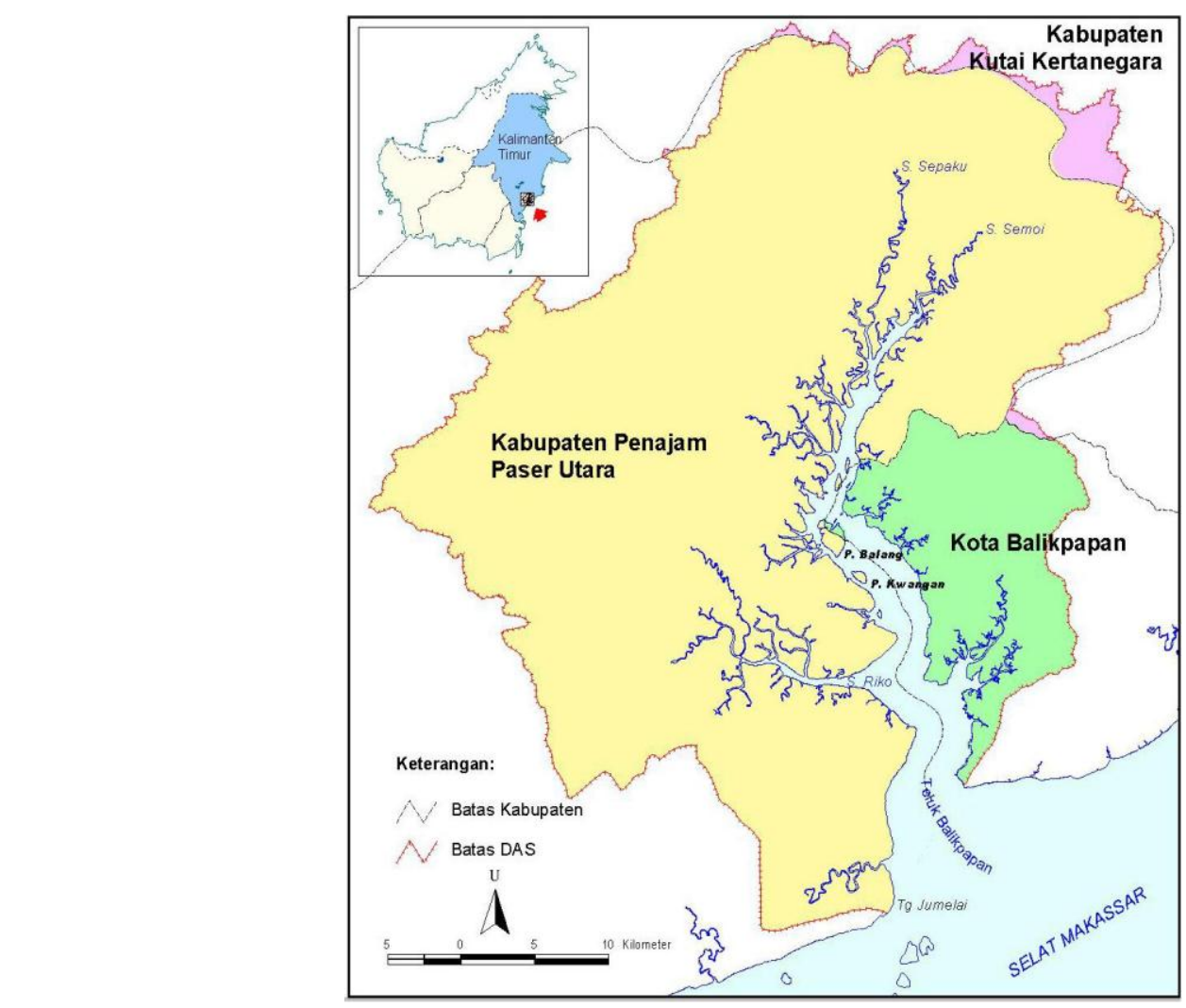

Sumber : Survei Lapangan dan Google Earth 2017

Gambar 1. Peta Orientasi Lokasi Penelitian
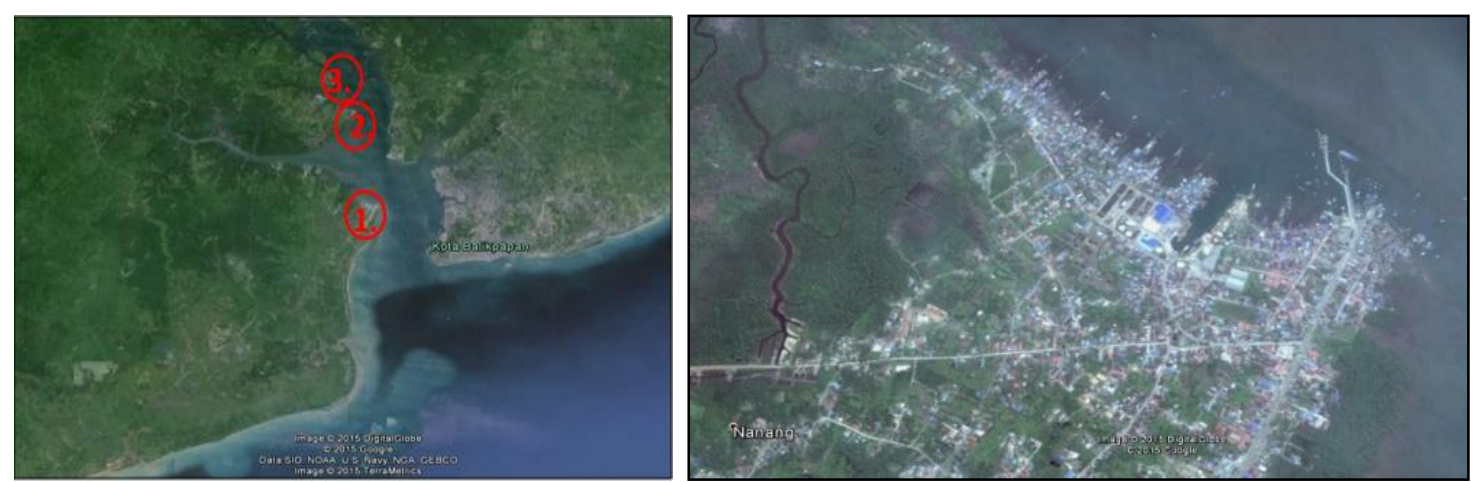

Sumber : Survei Lapangan dan Google Earth 2017

Gambar 2. Persebaran Masyarakat Bajo di Teluk Balikpapan (kiri) dan Permukiman Bajo di Kelurahan Penajam (kanan) 
Penelitian ini bertujuan untuk mengetahui kapasitas masyarakat Bajo dalam menghadapi perubahan lingkungan yang terjadi pada alam sekitarnya dengan memperhatikan pola perilaku bermukim Suku Bajo di Teluk Balikapapan yang masuk ke dalam lingkup wilayah Kabupaten Penajam Paser Utara. Selanjutnya, dilakukan perbandingan dari hasil kapasitas adaptasi dari lokasi studi yang berada di tiga kelurahan, yaitu Pantai Lango, Jenebora dan Kelurahan Penajam

Lokasi penelitian terletak di Teluk Balikpapan yaitu tiga kelurahan yang mayoritas dihuni oleh Masyarakat Suku Bajo. Pemukiman yang menjadi tempat tinggal Masyarakat Bajo terletak di atas air atau menjorok ke arah laut, namun tidak sedikit yang sudah mulai mendirikan rumah menjauh dari air. Kebanyakan dari mereka yang memilih pindah karena faktor ekonomi ataupun karena melakukan pernikahan dengan orang-orang luar/orang bukan Suku Bajo. Studi ini dilakukan perbandingan kapasitas adaptasi bermukim Masyarakat Bajo dalam menghadapi perubahan lingkungan sekitar yang diakibatkan oleh isu-isu pengembangan daerah pesisir terjadinya pencemaran-pencemaran lingkungan yang berasal dari perusahan-perusahan sekitar dan berdampak pada terganggunya mata pencaharian utama masyarakat Bajo sebagai nelayan. Gambar 4 berikut adalah skema penelitian yang dilakukan.

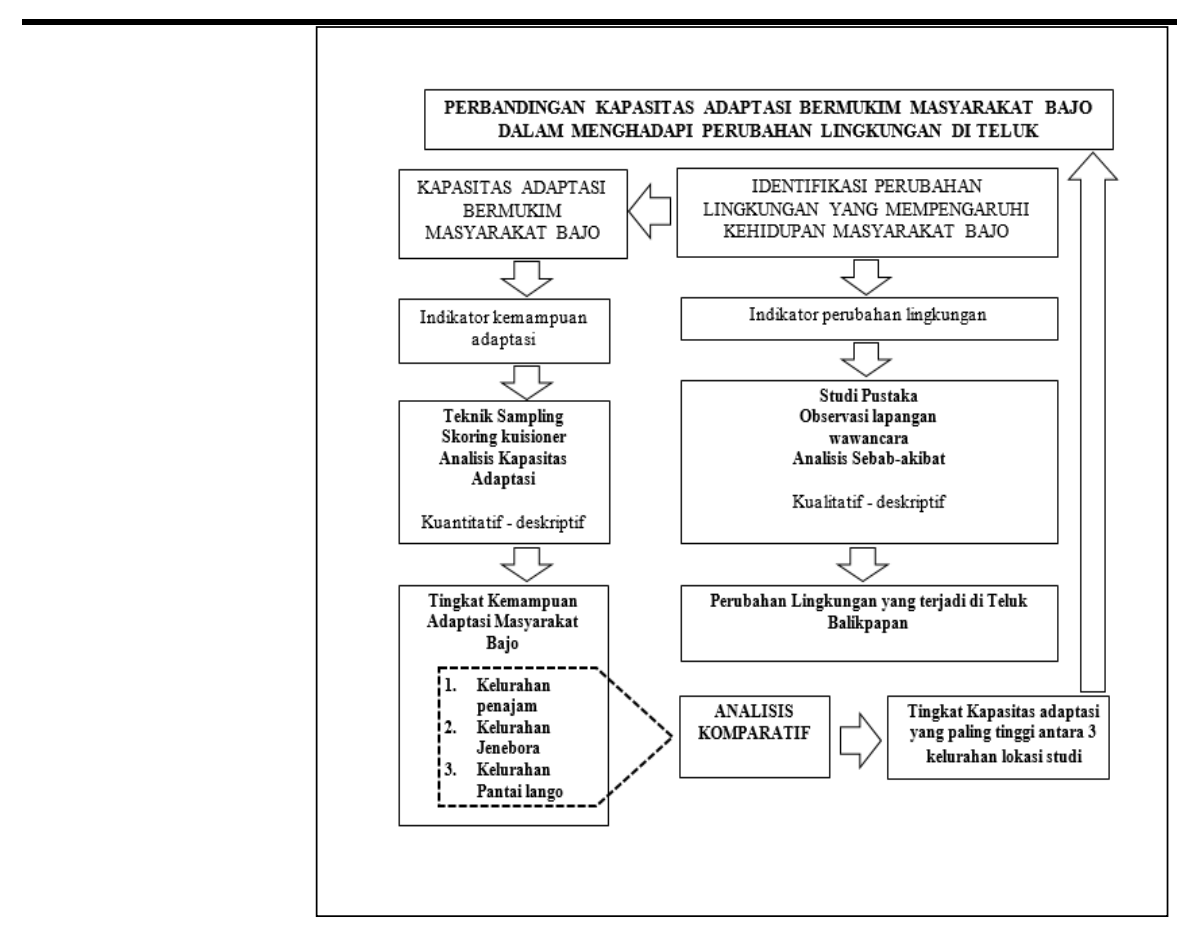

Gambar 3. Kerangka Kerja Penelitian

\section{METODE}

Penelitian ini diawali dengan observasi awal yang sudah dilakukan di Kabupaten Penajam Paser Utara selama kurun waktu 1 (satu) tahun terakhir yaitu antara tahun 20152016. Data primer adalah data yang diperoleh langsung dari informan atau pemasok melalui wawancara. Informan dipilih tidak berdasar jumlah karena tujuannya adalah mencari kebenaran, kerincian, dan keluasan informasi dari fenomena yang terjadi. Pemilihan informan diseleksi melalui : (i) mengetahui budaya mereka secara baik dan mempunyai pengalaman informal yang panjang (enkulturasi penuh); (ii) pernah mengalami sendiri (terlibat langsung) dalam suasana budaya, kejadian, peristiwa yang lampau (jika memungkinkan sampai sekarang); (iii) tidak menyadari adanya pengetahuan budaya lokal; 
(iv) mempunyai waktu yang cukup banyak untuk bekerjasama (informan utama) karena dilakukan berkali-kali dalam waktu yang lama; (v) tidak menganalisis, informan menggunakan bahasa mereka untuk mendeskripsikan berbagai kejadian dan tindakan tanpa menganalisis arti kejadian dan tindakan; (vi) dapat memberikan analisis tanpa interpretasi mengenai kejadian dari perspektif penduduk lokal.

\section{Teknik Pengumpulan Data}

Teknik wawancara yang digunakan dalam penelitian ini adalah wawancara mendalam (indepth-interview), yang dilakukan terhadap 12 narasumber paling relevan di lokasi penelitian. Adapun kriteria umum menjadi narasumber dalam penelitian ini adalah: Orang Bajo, yang tinggal cukup lama di lokasi (kalau mungkin semenjak lahir), punya pengetahuan dan pemehaman yang memadai terkait dengan perubahan yang ada, baik secara fisik maupun non fisik. Teknik observasi dalam penelitian ini digunakan untuk mencari fkta-fakta otentik berbagai perubahan yang ada di lapangan, yang akan membantu untuk proses pengambilan kesimpulan lewat cross check wawancara mendalam.

Teknik pengumpulan data lain yang dilakukan dalam penelitian ini adalah penyebaran kuisioner, yang sangat krusial untuk bisa mengukur perubahan apa yang terjadi menurut warga sendiri. Dibutuhkan sampel dari populasi di setiap kelurahan. Tabel di bawah menunjukkan jumlah KK pada setiap kelurahan yang diteliti.

Tabel 1. Jumlah KK setiap Kelurahan

\begin{tabular}{lc}
\hline \multicolumn{1}{c}{ Kelurahan } & Jumlah KK \\
\hline Penajam & 214 \\
Jenebora & 382 \\
Pantai Lango & 263 \\
\hline \multicolumn{2}{c}{ Sumber : Hasil Survey 2017 }
\end{tabular}

Dari jumlah KK tersebut dilakukan penghitungan sampel dengan metode Slovin, sebagai berikut :

$$
n=\frac{N}{1+N e^{2}}
$$

Dimana :

$n$ : Jumlah sampel

$\mathrm{N}$ : Jumlah populasi

e : Batas toleransi kesalahan (error tolerance)

Batas toleransi kesalahan ini dinyatakan dengan persentase. Semakin kecil toleransi kesalahan, semakin akurat sampel menggambarkan populasi. Dalam penelitian ini digunakan batas kesalahan $5 \%$.

- Kelurahan Penajam dengan jumlah KK sebanyak $214 \mathrm{KK}$ :

$n=\mathrm{N} /\left(1+\mathrm{N} \mathrm{e}^{2}\right)=214 \mathrm{KK} /\left(1+214 \times 0,05^{2}\right)=139 \mathrm{KK}$

- Kelurahan Jenebora dengan jumlah KK sebanyak $382 \mathrm{KK}$ :

$n=\mathrm{N} /\left(1+\mathrm{N} \mathrm{e}^{2}\right)=382 \mathrm{KK} /\left(1+382 \times 0,05^{2}\right)=195 \mathrm{KK}$

- Kelurahan Penajam dengan jumlah KK sebanyak $263 \mathrm{KK}$.

$n=\mathrm{N} /\left(1+\mathrm{N} \mathrm{e}^{2}\right)=263 \mathrm{KK} /\left(1+263 \times 0,05^{2}\right)=158 \mathrm{KK}$

Penelitian ini dilaksanakan di wilayah dengan status cukup mampu beradaptasi dan sulit untuk beradaptasi, dengan tujuan untuk: 
1. Mengetahui indeks kerentanan masyarakat dalam beradaptasi menghadapi perubahan adaptasi bermukim masyarakat Bajo yang rentan dengan perubahan lingkungan a) Membuat penilaian dan menghitung skor terhadap indikator kerentanan adaptasi.

\begin{tabular}{|c|c|}
\hline Kapasitas Adaptif & Penilaian \\
\hline Pendidikan & $\begin{array}{l}\text { Skor 0: Tidak Sekolah } \\
\text { Skor 1: SD } \\
\text { Skor 2: SMP } \\
\text { Skor 3: SMU } \\
\text { Skor 4: D3/PT }\end{array}$ \\
\hline Pengetahuan & $\begin{array}{l}\text { Terdapat } 11 \text { pertanyaan untuk mengetahui tingkat pengetahuan responden tentang } \\
\text { perubahan lingkungan, dengan penilaian sebagai berikut: } \\
\text { a. Untuk pertanyaan favorable jika menjawab benar diberi nilai } 1 \text { dan jika } \\
\text { menjawab salah diberikan nilai } 0 \text { (Nomor Pertanyaan: } 2,3,4,8,9 \text { ) } \\
\text { b. Untuk pertanyaan unfavorable jika menjawab benar diberi nilai } 0 \text { dan jika } \\
\text { menjawab salah diberi nilai } 1 \text { (Nomor Pertanyaan: } 1,5,6,7,10,11 \text { ). }\end{array}$ \\
\hline Persepsi & $\begin{array}{l}\text { Terdapat } 10 \text { pertanyaan untuk mengetahui persepsi responden tentang perubahan } \\
\text { lingkungan. Data persepsi responden menggunakan skala likert: Sangat Setuju (SS), } \\
\text { Setuju (S), Ragu-Ragu (R), Kurang Setuju (KS), Sangat Tidak Setuju (STS), dengan } \\
\text { penilaian: } \\
\text { a. Untuk pertanyaan favorable jika menjawab SS diberi nilai } 5 \text { dan jika menjawab } \\
\text { STS diberikan nilai } 1 \text { (Nomor Pertanyaan: } 6 \text { dan 8). } \\
\text { b. Untuk pertanyaan unfavorable jika menjawab SS diberi nilai } 0 \text { dan jika } \\
\text { menjawab STS diberi nilai } 1 \text { (Nomor Pertanyaan: } 1,2,3,4,5,7,9 \text {, dan 10). }\end{array}$ \\
\hline Kearifan Lokal & $\begin{array}{l}\text { Terdapat } 6 \text { pertanyaan untuk mengukur kearifan lokal di masyarakat. } \\
\text { Setiap jawaban 'iya' pada pertanyaan tersebut akan diberikan skore } 1 \text { dan jika } \\
\text { 'tidak' akan diberikan skor } 0\end{array}$ \\
\hline $\begin{array}{l}\text { Keterlibatan } \\
\text { Komunitas }\end{array}$ & $\begin{array}{l}\text { Terdapat } 3 \text { pertanyaan untuk mengukur keterlibatan komunitas. } \\
\text { Setiap jawaban 'iya' pada pertanyaan tersebut akan diberikan skor } 1 \text { dan jika 'tidak' } \\
\text { akan diberikan skor } 0\end{array}$ \\
\hline Kepemimpinan & $\begin{array}{l}\text { Terdapat } 11 \text { pertanyaan untuk mengukur kemampuan pemimpin dalam mengatur } \\
\text { suatu organisasi kewilayahan. } \\
\text { Setiap jawaban 'iya' pada pertanyaan tersebut akan diberikan skor } 1 \text { dan jika 'tidak' } \\
\text { akan diberikan skor } 0\end{array}$ \\
\hline Jaringan & $\begin{array}{l}\text { Terdapat } 2 \text { pertanyaan untuk mengetahui upaya suatu lembaga untuk menjalin } \\
\text { hubungan kerjasama dengan lembaga lain. } \\
\text { Setiap jawaban 'iya' pada pertanyaan tersebut akan diberikan skor } 1 \text { dan jika 'tidak' } \\
\text { akan diberikan skor } 0\end{array}$ \\
\hline $\begin{array}{l}\text { Ketersediaan } \\
\text { Informasi }\end{array}$ & $\begin{array}{l}\text { Terdapat } 2 \text { pertanyaan untuk mengetahui upaya yang dilakukan suatu lembaga } \\
\text { untuk mendapatkan informasi yang terkait dengan penyediaan air bersih } \\
\text { Setiap jawaban 'iya' pada pertanyaan tersebut akan diberikan skor } 1 \text { dan jika 'tidak' } \\
\text { akan diberikan skor } 0\end{array}$ \\
\hline $\begin{array}{l}\text { Keberadaan } \\
\text { Organisasi }\end{array}$ & $\begin{array}{l}\text { Terdapat } 6 \text { pertanyaan untuk mengetahui keberadaan organisasi di suatu wilayah } \\
\text { yang khusus dibentuk untuk menghadapi dampak perubahan lingkungan } \\
\text { Setiap jawaban 'iya' pada pertanyaan tersebut akan diberikan skor } 1 \text { dan jika 'tidak' } \\
\text { akan diberikan skor } 0\end{array}$ \\
\hline
\end{tabular}

b) Menghitung indikator kerentanan pada variabel yang terdapat di dalam indikator kerentanan, dengan cara sebagai berikut:

1) Mencari nilai rata-rata aktual $\left(\mathrm{X}_{\text {actual }}\right)=$ Skore Responden $1+$ Skore Responden $2+$ Skore Responden $3+\cdots . .$. Skore Responden $n$ Jumlah Responden (n)

2) Mencari nilai $X_{\text {maksimum }}=$ mencari nilai responden yang tertinggi

3) Mencari nilai $X_{\text {minimal }}=$ mencari nilai responden yang terendah

4) Jika sudah diketahui, maka hitunglah indeks kerentanan masing-masing variabel yang terdapat di dalam indikator dengan rumus sebagai berikut: 


$$
i=\frac{x \text { actual }-X \text { minimal }}{X \text { maksimal }-X \text { minimal }}
$$

5) Indeks yang telah dihasilkan, dikatergorikan kedalam 3 parameter, yaitu

\begin{tabular}{ll}
\hline \multicolumn{1}{c}{ Indikator } & Rentang \\
\hline High Vulnerability (Kerentanan Tinggi) & $0,00-0,33$ \\
Moderate Vulnerability (Kerentanan & $0,34-0,66$ \\
Sedang) & \\
Highly Resilient (Tangguh) & $0,67-1,00$ \\
\hline
\end{tabular}

6) Membuat kesimpulan indeks kerentanan tiap indicator dengan cara menghitung nilai rata-rata yang telah dihasilkan pada variabel

Rata-Rata Kapasitas adaptif $=$

Indikator (Pendidikan+Pengetahuan+Persepsi +Kearifan Lokal+Keteribatan Komunitas+ Kepemimpinan+Jaringan+KetersediaanInformasi+Keberadaan Organisasi

\section{Analisis Fishbone}

Alat analisis yang digunakan adalah cause-and-effect diagram, yaitu suatu grafik yang menunjukkan hubungan antara suatu masalah dan kemungkinan penyebabnya. Diagram ini dikenal sebagai diagram tulang ikan (fishbone diagram) atau "Ishikawa Diagram" (Ilie, 2010). Cause-and-effect diagram disebut juga sebagai "diagram tulang ikan" karena dibuat menyerupai tulang/rangka seekor ikan, dengan kategori penyebab utama disusun membentuk seperti tulang yang dihubungkan dengan tulang belakang ikan, seperti ditunjukkan pada diagram $\mathrm{x}$.

Dari masing-masing tulang yang besar, mungkin ada tulang lebih kecil yang menyoroti aspek lebih spesifik suatu penyebab tertentu, dan bisa terdiri dari tiga cabang atau lebih.

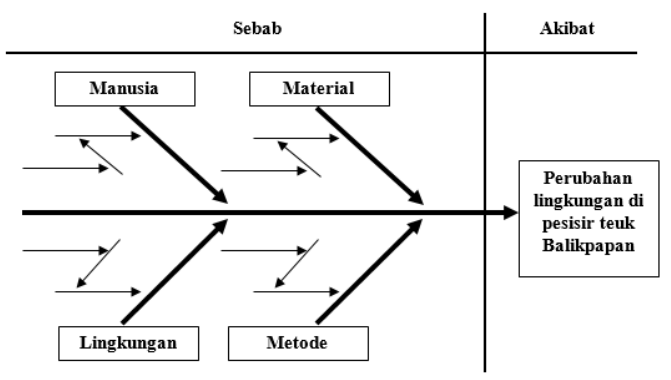

Sumber: modifikasi dari (Ilie, 2010)

Gambar 5. Diagram Sebab-Akibat Fishbone Analysis

\section{Analisis Komparasi, Adaptasi dan Kapasitas Adaptasi}

Istilah komparasi berarti perbandingan, "komparasi" atau komparasional diambil dari kata "comparison" dengan arti "perbandingan" atau "pembandingan", sehingga penelitian ilmiah komparatif adalah penelitian/kajian berdasarkan perbandingan. Lebih lanjut, Arikunto (Arikunto, 2002)menyebutkan bahwa "penelitian komparasi yaitu ingin membandingkan dua atau tiga kejadian dengan melihat penyebab-penyebabnya".

Pendapat yang lain menyatakan bahwa penelitian komparasi adalah jenis penelitian deskriptif yang ingin mencari jawaban secara mendasar tentang sebab-akibat, dengan 
menganalisis faktor-faktor penyebab terjadinya ataupun munculnya suatu fenomena tertentu. Penelitian komparatif memiliki tujuan, yaitu ; 1. Untuk membandingkan persamaan dan perbedaan dua atau lebih fakta-fakta dan sifat-sifat objek yang di teliti berdasarkan kerangka pemikiran tertentu, 2. Untuk membuat generalisasi tingkat perbandingan berdasarkan cara pandang atau kerangka berpikir tentu, 3. Untuk menentukan mana yang lebih baik atau mana yang sebaiknya dipilih, 4. Untuk menyelidiki kemungkinan hubungan sebab-akibat dengan cara berdasar atas pengamatan terhadap akibat yang ada dan mencari kembali faktor yang mungkin menjadi penyebab melalui data tertentu (Nazir, 2005).

Adaptasi adalah cara makhluk hidup menyesuaikan diri terhadap lingkungannya, dan adaptasi merupakan konsep yang menonjol di tahun 1980-an (Engle, 2011) dan adaptasi merupakan perubahan yang dibuat oleh individu-individu didalam identitas afektif dan kognitif mereka dan di dalam perilaku interaktif mereka yang berkaitan dengan lingkungan budaya baru. Studi mengenai adaptasi sudah mulai marak, dengan yang popular adalah meliputi adaptasi terhadap perubahan iklim (climate change), misalkan saja yang dikaji oleh Ford (Ford, Berrang-ford, King, \& Furgal, 2010) dan juga Egyir (Egyir, Ofori, Antwi, \& Ntiamoa-baidu, 2015). Sementara, riset mengenai kapasitas adaptasi dan juga perubahan dalam masyarakat, terutama masyarakat adat-terasing (indigenous people) sudah mulai dikaji antara lain oleh Aldon (Aldon, Forbes, \& Ang, 2016), dan juga Apgar dkk. (Apgar, Allen, Moore, \& Ataria, 2015), dengan berbagai kasus antara lain di Philipina, Kanada, Ghana dan juga Panama.

Kapasitas adaptasi, adalah faktor yang berhubungan dengan kemampuan merespon perubahan iklim yang diwujudkan melalui adaptasi, ketersediaan institusi, pemerintah dan lembaga yang efektif. Kapasitas adaptasi perlu dibangun terutama pada kawasan yang rawan bencana dengan melakukan berbagai tindakan adaptasi. Gupta (Gupta et al., 2010) melihat kapasitas adaptasi lebih terfokus pada lembaga sebagai pelaku sosial untuk menangani jangka panjang dari perubahan iklim.

Arti dan utilitas kapasitas adaptif telah banyak diperdebatkan (Davidson, 2010; Klein, Nicholls, \& Thomalla, 2003). Namun, sebagian besar ilmuwan sosial menghubungkan kapasitas adaptif terhadap dua konsep terkait: ketahanan dan kerentanan, menggambarkan kontribusi relatif dari ketahanan dan kerentanan paradigma, dan berpendapat bahwa fokus pada kapasitas adaptif, sebuah konsep yang merupakan komponen dari kedua paradigma, dan keterkaitan untuk adaptasi memiliki potensi untuk menggabungkan kekuatan dari kedua di masa depan penelitian (Engle, 2011).

Analisis adaptasi umumnya didekati secara tidak langsung baik dari kerentanan atau paradigma ketahanan. Sementara adaptasi belum tentu di pusat ketahanan atau kerentanan penelitian, kapasitas adaptif adalah atribut fundamental yang menyatukan literatur ini (Engle, 2011). Misalnya, kapasitas adaptif dikreditkan untuk mengurangi kerentanan dan meningkatkan ketahanan. Meskipun dalam perbandingan itu terbelakang, sebuah literatur yang berbeda pada adaptasi sebagai domain pengetahuan independen juga muncul (Janssen \& Ostrom, 2006). Gudykunst dan Kim (Gudykunst,. Kim, 2003) mengemukakan bahwa semua orang dapat menjadi strangers dan memerlukan proses adaptasi ketika memasuki lingkungan budaya baru atau tidak di kenal. Kemampuan adaptif merupakan bagian dari upaya untuk meningkatkan kesadaran individu maupun kelompok masyarakat dalam mengantisipasi perubahan iklim yang diwujudkan dalam implementasi perubahan perilaku adaptasi, dimana hal ini diperlukan untuk mempersiapkan diri terhadap segala kemungkinan perubahan di masa mendatang (Spearman, M., \& McGray, 2011).

\section{HASIL DAN PEMBAHASAN}

Teluk Balikpapan adalah sebuah teluk kecil di Indonesia yang merupakan bagian dari Pulau Kalimantan. Teluk Balikpapan terletak di sebelah Barat Selat Makassar, atau sekitar 
Barat Daya dari Samudera Pasifik. Teluk Balikpapan berbatasan dengan beberapa daerah, antara lain sebagai berikut :
Sebelah Utara
: Kota Balikpapan
Sebelah Selatan
: Penajam
Sebelah Barat
: Kabupaten Penajam Paser Utara
Sebelah Timur
: Selat Makassar

Teluk Balikpapan memiliki luas daerah aliran sungai (DAS) 211.456 Hektar dan perairan seluas 16.000 hektar. Sebanyak 54 Sub-Das mengnduk di wilayah teluk ini, termasuk salah satunya adalah DAS Sei Wein yang sudah menjadi hutan lindung dan dikenal dengan Hutan Lindung Sungai Wain yang dikelola oleh Pemerintah Kota Balikpapan (Makkinuddin, 2010).

Berbagai obyek vital nasional maupun sarana produksi ekonomi kerakyatan sudah berlangsung di kawasan ini. Kilang minyak Pertamina yang melayani kebutuhan masyarakat di wilayah Indonesia Timur (Kalimantan, Sulawesi dan Papua). Kilang ini membutuhkan air untuk produksi maupun kebutuhan domestik karyawannya dalam jumlah yang luar biasa besar dari kawasan Teluk Balikpapan.

\section{Perubahan Lingkungan Pesisir di Teluk Balikpapan}

Perairan Teluk Balikpapan, merupakan sistem perairan yang relatif tertutup. Sebab, tak ada sungai besar yang berair ke hulu Teluk Balikpapan. Pola arus air teluk kebanyakan tak keluar ke Perairan Selat Makassar. Ia hanya bergerak dari hulu ke hilir, lalu kembali lagi lewat pasang surut jika ini terus menerus terjadi, dalam jangka panjang akan menyebabkan polusi ekstrim. Semakin banyaknya kegiatan industri yang dilakukan di Teluk Balikpapan membuat wajah Teluk Balikpapan semakin lama semakin berubah namun mengarah pada kerusakan lingkungan akibat kegiatan tidak bertanggung jawab yang dilakukan oleh manusia, berikut beberapa kegiatan yang dilakukan oleh manusia di Pesisir Teluk Balikpapan.

Tabel 3. Kegiatan di Pesisir Teluk Balikpapan

\begin{tabular}{|c|c|c|c|}
\hline No & Lokasi & Kegiatan & Foto Lokasi \\
\hline 1 & $\begin{array}{l}\text { Kabupaten Penajam Paser Utara, } \\
\text { Kecamatan Penajam, Kelurahan } \\
\text { Penajam, Pelabuhan Ferry } \\
\text { Penajam, }\end{array}$ & $\begin{array}{l}\text { Aktivitas pelayaran di Teluk } \\
\text { Balikpapan (penyeberangan) }\end{array}$ & \\
\hline 2 & $\begin{array}{l}\text { Kota Balikpapan, Kecamatan } \\
\text { Balikpapan Barat, Kelurahan } \\
\text { Kampung Baru Ulu, Pelabuhan } \\
\text { Speed. }\end{array}$ & $\begin{array}{l}\text { Aktivitas Pelayaran di teluk } \\
\text { Balikpapan (penyeberangan) }\end{array}$ & \\
\hline 3 & $\begin{array}{l}\text { Kota Balikpapan, Kecamatan } \\
\text { Balikpapan Selatan, Kelurahan } \\
\text { Prapatan, Pelabuhan Semayang. }\end{array}$ & $\begin{array}{l}\text { Aktivitas Pelayaran di teluk } \\
\text { Balikpapan (penyeberangan) }\end{array}$ & \\
\hline 4 & $\begin{array}{l}\text { Kabupaten Penajam Paser Utara, } \\
\text { Kecamatan Penajam, Kelurahan } \\
\text { Penajam }\end{array}$ & Terminal minyak dan gas PT.C. & \\
\hline
\end{tabular}




\begin{tabular}{|c|c|c|c|}
\hline No & Lokasi & Kegiatan & Foto Lokasi \\
\hline 5 & $\begin{array}{l}\text { Kabupaten Penajam Paser Utara, } \\
\text { kecamatan Penajam, Kelurahan } \\
\text { Buluminung. }\end{array}$ & Pelabuhan ESB & \\
\hline 6 & $\begin{array}{l}\text { Kabupaten Penajam, Kecamatan } \\
\text { Penajam, kelurahan Buluminung }\end{array}$ & $\begin{array}{l}\text { Floating dock, tempat pelepasan } \\
\text { kapal besar dan perbaikan, PT. M. }\end{array}$ & \\
\hline 7 & $\begin{array}{l}\text { Kabupaten Penajam Paser Utara, } \\
\text { Kecamatan Penajam, Kelurahan } \\
\text { Jenebora. }\end{array}$ & $\begin{array}{l}\text { sebuah perusahaan KI dengan bidang } \\
\text { usaha sebagai penyedia bahan kayu } \\
\text { lapis Jenebora dengan nama PT. IDD } \\
\text { Co Ltd. }\end{array}$ & \\
\hline
\end{tabular}

Kabupaten Penajam Paser Utara,

8 Kecamatan Penajam, Kelurahan Jenebora.

Kabupaten Penajam Paser Utara,

9 Kecamatan Penajam, Kelurahan Pantai Lango.

Bekas galian tambang

Pembangunan jembatan menuju Pulau Balang

Kota Balikpapan, Kecamatan

10 Balikpapan Barat, Kelurahan Kariangau.

Kota Balikpapan, Kecamatan

11 Balikpapan Barat, Kelurahan Kariangau.

Kota Balikpapan, Kecamatan 12 Balikpapan Barat, Kelurahan Kariangau.

Pabrik pengolahan kelapa sawit

\section{PLTU Kariangau}

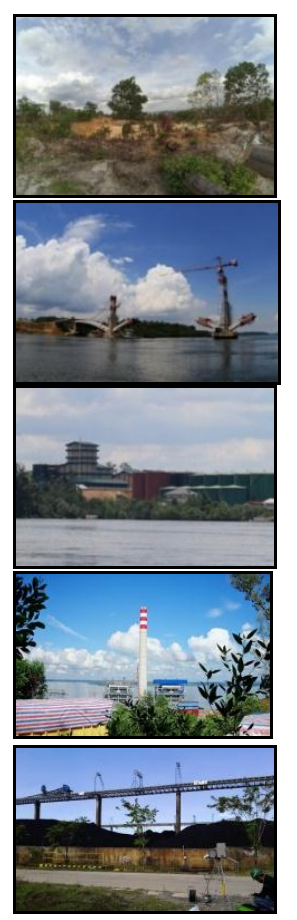

Kota Balikpapan, Kecamatan

13 Balikpapan Barat, Kelurahan Kariangau.

Kota Balikpapan, Kecamatan

14 Balikpapan Barat, Kelurahan Kariangau.

PT. KK, terminal curah kering untuk batu bara dan terminal curah cair untuk minyak kelapa sawit

PT. Petrosea Offshore Supply Base, kontraktor pertambangan.

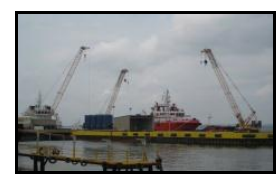

Intipratama Global Service

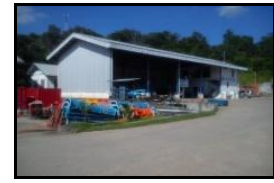

Kota Balikpapan, Kecamatan

Emeco, PT. Prima Traktor Indo Nusa.

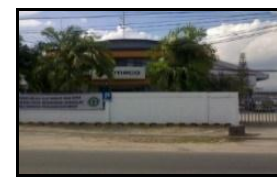




\begin{tabular}{llll}
\hline \multicolumn{1}{c}{ Lokasi } & Kegiatan & Foto Lokasi \\
\hline 16 & $\begin{array}{l}\text { Kota Balikpapan, Kecamatan } \\
\text { Balikpapan Barat, Kelurahan } \\
\text { Kariangau. }\end{array}$ & Pertamina & \\
\hline
\end{tabular}

Sumber : hasil survey lapangan, 2017

\section{Abrasi Pantai, Kenaikan Muka Air Laut dan Pencemaran-Gangguan Lingkungan di Teluk Balikpapan}

Kenaikan muka air laut merupakan fenomena naiknya muka air laut akibat pertambahan volume air laut. Perubahan tinggi permukaan air laut dapat dilihat sebagai suatu fenomena alam yang terjadi secara periodik maupun menerus. Perubahan secara periodik dapat dilihat dari fenomena pasang surut air laut, sedangkan kenaikan air laut yang menerus adalah seperti yang teridentifikasi oleh pemanasan global.

Dari hasil wawancara yag dilakukan, secara umum pencemaran yang terjadi dikarenakan limbah dari perusahaan yang langsung dibuang di laut tanpa diolah sebelumnya. Selain itu ada pencemaran di pesisir yang berasal dari masyarakat pesisirnya sendiri yang membuang sampah rumah tangga langsung ke laut tanpa diproses atau dibakar. Kotornya pantai di Pesisir Teluk Balikpapan akan terlihat ketika air mulai pasang dan membawa berbagai jenis sampah dan tertinggal ketika air laut mulai surut.

Terdapat 12 orang narasumber yang menanggapi perubahan lingkungan terkait pada gangguan lingkungan pesisir, yaitu sebagian besar mengungkapkan gangguan lingkungan yang terjadi di wilayahnya adalah sebatas gangguan kebisingan dari aktivitas industri di sekitar rumah. Narasumber lain menambahkan bahwa adanya gangguan lingkungan berupa bau tidak sedap yang berasal dari sampah-sampah yang dibuang sembarangan oleh masyarakat tanpa diolah terlebih dahulu.

\section{Dampak Perubahan dan Kapasitas Adaptasi Masyarakat Bajo}

Dari aspek fisik, lingkungan Kelurahan Penajam telah mengalami perubahan lingkungan ke arah yang tidak baik dan berdampak buruk bagi kehidupan sekitar, pemicu perubahan tersebut antara lain pencemaran air yang sumbernya berasal dari limbah pabrik PT. C. atau buangan minyak pada aktivitas pelayaran di Pelabuhan Speed Penajam. Selain itu kerusakan tanaman mangrove mengakibatkan terancam ekosistem di belakangnya. Hal tersebut juga terjadi di Kelurahan Jenebora dan Pantai Lango, meskipun intensitas pelayarannya tidak sepadat di jalur Balikpapan-Penajam, namun tepat dihadapan Kelurahan Jenebora dan Kelurahan Pantai Lango terbentang luas area Industri Kariangau.

Dari aspek ekonomi, narasumber menyatakan tentang berkurangnya pendapatan karena hasil tangkapan juga berkurang, pendapatan tidak menentu, kesulitan membiayai hidup dan membiayai bahan bakar untuk melaut karena tingkat ekonomi rendah. Sedangkan kebutuhan semakin banyak dengan harga yang tinggi, sementara skill bekerja hanya seputar bidang kelautan. Perubahan lingkungan mengakibatkan banyak kerugian bagi masyarakat yang tinggal di wilayah pesisir yang banyak di huni oleh masyarakat Suku Bajo dan Suku Bugis. Dari aspek sosial, tidak adanya interaksi yang intens terhadap masyarakat dengan tingkat ekonomi yang lebih tinggi adanya disparitas yang sangat tinggi terhadap masyarakat sekitar. Dari aspek budaya, masyarakat Bajo tinggal di pesisir awalnya karena nenek moyang mereka telah lama tinggal sebelumnya, karena itu mereka tidak akan pindah ketika aktivitas yang bisa dilakukan hanyalah sebagai seorang nelayan.

Kapasitas adaptasi atau kemampuan masyarakat Bajo untuk beradaptasi menghadapi perubahan lingkungan di Teluk Balikpapan dapat dilihat dari cara mereka menafkahi 
keluarga mereka, masyarakat pesisir atau masyarakat Bajo yang sadar akan perubahan lingkungan pesisir Teluk Balikpapan akan mencoba usaha baru untuk menghidupi keluarganya, pada umumnya hampir seluruh masyarakat Bajo di Teluk Balikpapan bekerja sebagai nelayan dan hanya sebagian yang memiliki usaha untuk menghidupi mereka disaat mereka tidak melaut.

Untuk bertahan hidup masyarakat harus memiliki keahlian lain selain di bidang kelautan. Beberapa masyarakat Bajo di Pesisir Teluk Balikpapan memilih untuk menekuni pekerjaan lain, namun masih menjaga kebiasaannya untuk pergi melaut dan beberapa di antara mereka benar-benar meninggalkan lautan, dan memilih pekerjaan yang lebih menjanjikan di daratan.

\section{Analisa Perbandingan Kapasitas Adaptasi di Pesisir Teluk Balikpapan}

Proses identifikasi masalah perubahan lingkungan di Pesisir Teluk Balikpapan dilakukan dengan menggunakan diagram fishbone dimana akan dicari sebab-akibat dari terjadinya perubahan lingkungan di lokasi ini. Diagram fishbone dapat dilihat pada gambar di bawah ini.

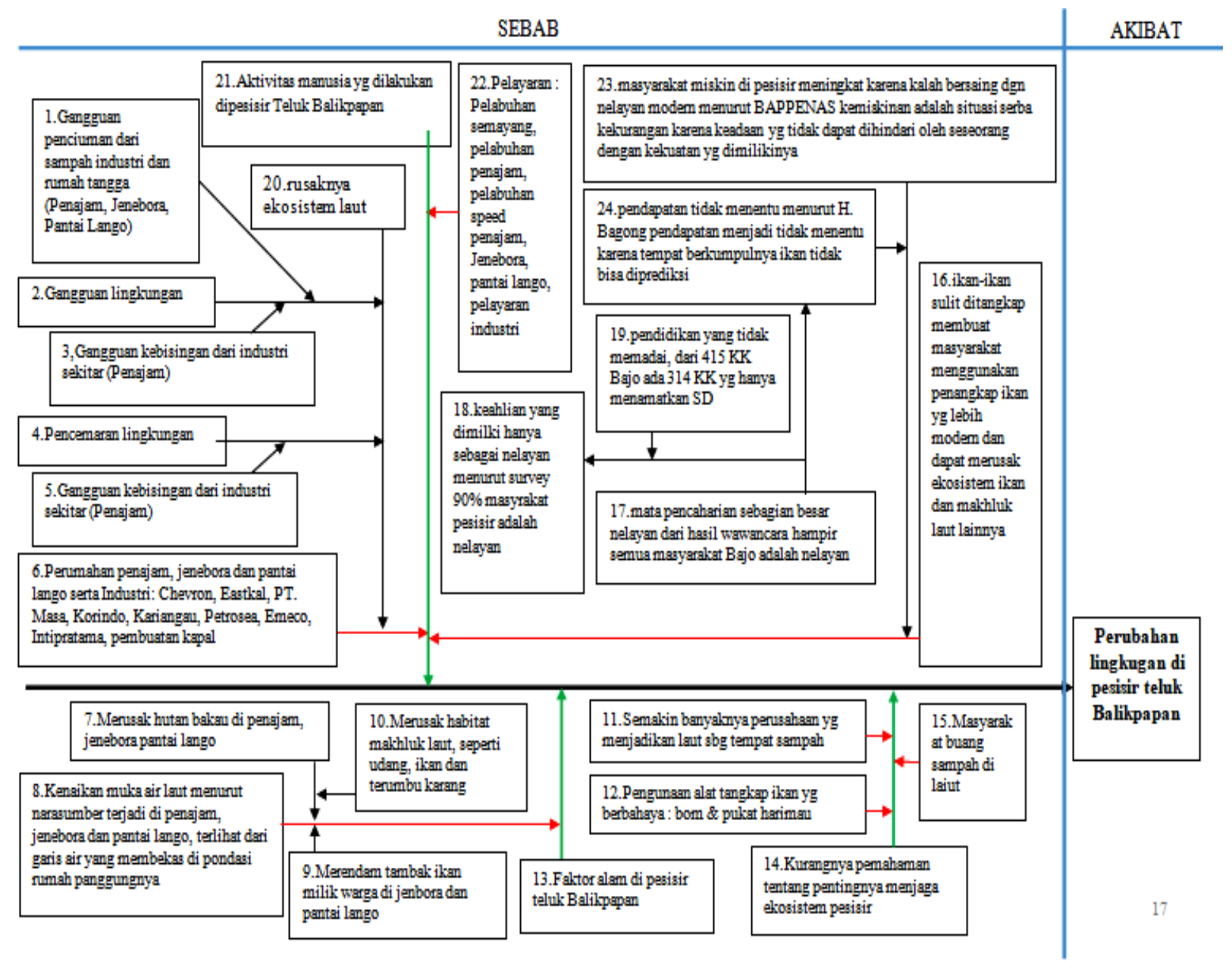

Gambar 6. Diagram Fish Bone Perubahan Lingkungan di Teluk Balikpapan 


\section{Analisa Kapasitas Adaptasi Masyarakat Bajo di Pesisir Teluk Balikpapan}

Analisis ini dilakukan dengan menghitung nilai rata-rata kapasitas adaptasi di Pesisir Teluk Balikpapan. Indikator dari kapasitas adaptif tersebut diukur untuk menentukan kerentanan dalam kapasitas adaptif. Sebelum melakukan penghitungan terhadap kerentanan terlebih dahulu dlakukan uji vaiditas pada kuesioner yang disebarkan.

\section{Uji Validitas}

Pada uji validitas untuk Kelurahan Penajam terdapat 4 pertanyaan yang tidak valid pada faktor pengetahuan dari 11 pertanyaan dan sisanya 7 pertanyaan adalah valid. Sementara untuk pertanyaan pada faktor kearifan lokal, keterlibatan komunitas, jaringan dan ketersediaan info memiliki pertanyaan yang valid dari semua pertanyaannya.

Pada uji validitas untuk Kelurahan Jenebora dari 11 pertanyaan pada faktor pengetahuan semua pertanyaan adalah valid, sedangkan untuk pertanyaan pada faktor kearifan lokal, keterlibatan komunitas, jaringan dan ketersediaan info memiliki pertanyaan yang valid dari semua pertanyaannya. Pada uji validitas untuk Kelurahan Pantai Lango dari 11 pertanyaan pada faktor pengetahuan hanya 1 pertanyaan yang tidak valid, sedangkan unutk pertanyaan pada faktor kearifan lokal, keterlibatan komunitas, kepemimpinan, jaringan dan ketersediaan info memiliki pertanyaan yang valid dari semua pertanyaannya.

Dari hasil kuesioner ditemukan nilai $\mathrm{x}$ actual berdasarkan skor seluruh responden di bagi dengan jumlah responden, setelah itu mencari skor responden yang paling tinggi sebagai nilai $\mathrm{x}$ maksimum dan nilai x minimum lalu menentukan nilai kerentanan. Lebih jelasnya dapat dilihat pada Tabel 4 sampai Tabel 12 di bawah ini:

Tabel 4. Indeks Kerentanan Pendidikan

\begin{tabular}{lccc}
\hline \multicolumn{1}{c}{ Indeks Kerentanan Pendidikan } & Penajam & Jenebora & Pantai Lango \\
\hline nilai actual & 1,55 & 1,37 & 1,48 \\
nilai x maksimum & 3 & 3 & 3 \\
nilai x minimum & 1 & 1 & 1 \\
nilai actual - nilai minimal & 0,27 & 0,18 & 0,24 \\
nilai maksimum - nilai minimum & & &
\end{tabular}

Berdasarkan tabel 4 di atas, maka bisa disimpulkan bahwa ketiga kelurahan memiliki indeks kerentanan pendidikan yang tinggi, yaitu pada nilai indeksnya di bawah o,33.

Tabel 5. Indeks Kerentanan Pengetahuan

\begin{tabular}{lccc}
\hline \multicolumn{1}{c}{ Indeks Kerentanan Pengetahuan } & Penajam & Jenebora & Pantai Lango \\
\hline nilai actual & 8,94 & 9,63 & 10 \\
nilai x maksimum & 10 & 11 & 11 \\
nilai x minimum & 7 & 5 & 7 \\
nilai actual - nilai minimal & 0,64 & 0,77 & 0,75 \\
nilai maksimum - nilai minimum & &
\end{tabular}

Sumber: hasil analisa

Berbeda dengan aspek pendidikan, dari sisi pengetahuan berdasarkan tabel 5 di atas, maka bisa disimpulkan bahwa dua kelurahan (Jenebora dan Pantai Lango) memiliki indeks kerentanan pengetahuan yang rendah, yaitu pada selang di atas 0,67 , sementara kelurahan yang lainnya (Penajam) ada pada selang kerentanan sedang (nilai indeks antara 0,34-0,66) 
Tabel 6. Indeks Kerentanan Persepsi

\begin{tabular}{lccc}
\hline \multicolumn{1}{c}{ Indeks Kerentanan Persepsi } & Penajam & Jenebora & Pantai Lango \\
\hline nilai actual & 35,46 & 35,23 & 34,55 \\
nilai x maksimum & 43 & 42 & 41 \\
nilai x minimum & 25 & 25 & 25 \\
$\quad$ nilai actual - nilai minimal & $\mathbf{0 , 5 8}$ & $\mathbf{0 , 6 0}$ & $\mathbf{0 , 5 9}$ \\
\hline nilai maksimum - nilai minimum & & & \\
\hline
\end{tabular}

Berdasarkan tabel 6 di atas, maka bisa disimpulkan bahwa ketiga kelurahan memiliki indeks kerentanan persepsi yang sedang, yaitu pada nilai indeksnya ada di selang $0,34-$ 0,66 .

Tabel 7. Indeks Kerentanan Kearifan Lokal

\begin{tabular}{lccc}
\hline \multicolumn{1}{c}{$\begin{array}{c}\text { Indeks Kerentanan } \\
\text { Kearifan Lokal }\end{array}$} & Penajam & Jenebora & $\begin{array}{c}\text { Pantai } \\
\text { Lango }\end{array}$ \\
\hline nilai actual & 5,14 & 4,56 & 4,17 \\
nilai x maksimum & 6 & 6 & 6 \\
$\begin{array}{l}\text { nilai x minimum } \\
\text { nilai actual - nilai minimal }\end{array}$ & 3 & 3 & 2 \\
$\begin{array}{l}\text { nilai maksimum - nilai } \\
\text { minimum }\end{array}$ & 0,71 & 0,52 & 0,54 \\
\hline
\end{tabular}

Berdasarkan sisi kearifan local, menurut tabel 7 di atas, maka bisa disimpulkan bahwa dua kelurahan (Jenebora dan Pantai Lango) memiliki indeks kerentanan kearifan local yang sedang, yaitu pada selang nilai indeks antara 0,34-0,66, sementara kelurahan yang lainnya (Penajam) ada pada selang kerentanan rendah, yaitu nilai indeks di atas o,67.

Tabel 8. Indeks Kerentanan Keterlibatan Komunitas

\begin{tabular}{lccc}
\hline \multicolumn{1}{c}{ Indeks Kerentanan keterlibatan komuitas } & Penajam & Jenebora & Pantai Lango \\
\hline nilai actual & 0,45 & 0,04 & 0,11 \\
nilai x maksimum & 3 & 2 & 2 \\
nilai x minimum & 0 & 0 & 0 \\
nilai actual - nilai minimal & 0,15 & 0,02 & 0,05 \\
nilai maksimum - nilai minimum & & & \\
\hline
\end{tabular}

Berdasarkan tabel 8 di atas, maka bisa disimpulkan bahwa ketiga kelurahan memiliki indeks kerentanan keterlibatan komunitas yang tinggi, yaitu pada nilai indeksnya ada di bawah nilai 0,33.

Tabel 9. Indeks Kerentanan Kepemimpinan

\begin{tabular}{lccc}
\hline \multicolumn{1}{c}{ Indeks Kerentanan Kepemimpinan } & Penajam & Jenebora & Pantai Lango \\
\hline nilai actual & 10,58 & 9,41 & 8,31 \\
nilai x maksimum & 11 & 11 & 11 \\
nilai x minimum & 8 & 4 & 4 \\
nilai actual - nilai minimal & 1,29 & 0,77 & 0,61 \\
nilai maksimum - nilai minimum & & & \\
\hline
\end{tabular}

Berdasarkan sisi kepemimpinan, menurut tabel 9 di atas, maka bisa disimpulkan bahwa dua kelurahan (Jenebora dan Penajam) memiliki indeks kerentanan kepemimpinan yang rendah, yaitu pada nilai indeks di atas 0,66. Sementara kelurahan yang lainnya (Pantai Lango) ada pada selang kerentanan sedang, yaitu nilai indeks diantara 0,34-0,66.

Tabel 10. Indeks Kerentanan Jaringan

\begin{tabular}{lccc}
\hline \multicolumn{1}{c}{ Indeks Kerentanan Jaringan } & Penajam & Jenebora & Pantai Lango \\
\hline nilai actual & 0,10 & 0,04 & 0,08 \\
nilai x maksimum & 2 & 2 & 2 \\
\hline
\end{tabular}




\begin{tabular}{|c|c|c|c|}
\hline Indeks Kerentanan Jaringan & Penajam & Jenebora & Pantai Lango \\
\hline nilai $\mathrm{x}$ minimum & 0 & 0 & 0 \\
\hline$\frac{\text { nilai actual }- \text { nilai minimal }}{\text { nilai maksimum - nilai minimum }}$ & 0,05 & 0,02 & 0,04 \\
\hline
\end{tabular}

Berdasarkan tabel 10 di atas, maka bisa disimpulkan bahwa ketiga kelurahan memiliki indeks kerentanan jaringan yang tinggi, yaitu pada nilai indeksnya ada di bawah nilai 0,33.

Tabel 11. Indeks Kerentanan Ketersediaan Informasi

\begin{tabular}{lccc}
\hline \multicolumn{1}{c}{ Indeks Kerentanan Ketersediaan Informasi } & Penajam & Jenebora & Pantai Lango \\
\hline nilai actual & 0,15 & 0,02 & 0,16 \\
nilai x maksimum & 2 & 2 & 2 \\
nilai x minimum & 0 & 0 & 0 \\
nilai actual - nilai minimal & 0,07 & 0,01 & 0,08 \\
\hline nilai maksimum - nilai minimum & & & \\
\hline
\end{tabular}

Sama dengan variable sebelumnya, berdasarkan tabel 11 di atas, maka bisa disimpulkan bahwa ketiga kelurahan memiliki indeks kerentanan ketersediaan informasi yang tinggi, yaitu pada nilai indeksnya ada di bawah nilai 0,33.

Tabel 12. Indeks Kerentanan Keberadaan Organisasi

\begin{tabular}{lccc}
\hline \multicolumn{1}{c}{ Indeks Kerentanan Keberadaan Organisasi } & Penajam & Jenebora & Pantai Lango \\
\hline nilai actual & 0,10 & 0,03 & 0,13 \\
nilai x maksimum & 2 & 2 & 2 \\
nilai x minimum & 0 & 0 & 0 \\
nilai actual - nilai minimal & 0,05 & 0,01 & 0,06 \\
nilai maksimum - nilai minimum & & & \\
\hline
\end{tabular}

Sama dengan 2 variable sebelumnya, berdasarkan tabel 12 di atas, maka bisa disimpulkan bahwa ketiga kelurahan memiliki indeks kerentanan keberadaan organisasi yang tinggi, yaitu pada nilai indeksnya ada di bawah nilai 0,33.

\section{Analisis Perbandingan Kapasitas Adaptasi Masyarakat Bajo dari Tiga Lokasi Studi}

Pada masing-masing kelurahan memiliki nilai kerentanan rata-rata, untuk Kelurahan Penajam nilai rata-rata kerentanannya adalah 0,42 yang berarti memiiki kerentanan sedang.

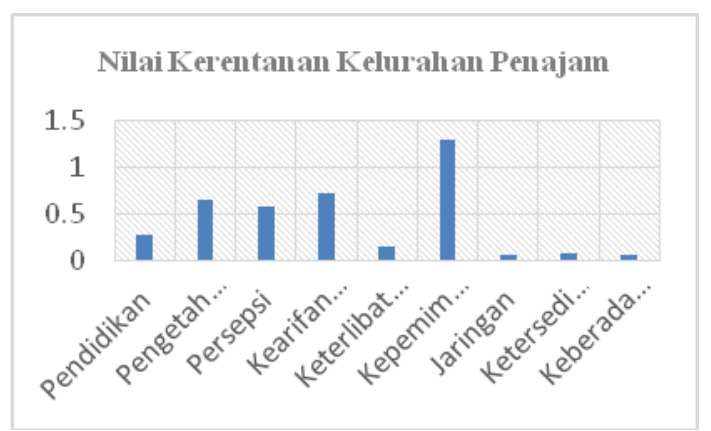

\section{Gambar 7. Grafik Nilai Kerentanan Kelurahan Penajam}

Sementara itu, Kelurahan Jenebora nilai rata-rata kerentanannya adalah 0,32 yang berarti memiliki kerentanan tinggi, dan Kelurahan Pantai Lango juga memiliki kerentanan tinggi dengan nilai kerentanan sebesar 0,32.Nilai kerentanan pada Kelurahan Penajam dapat dilihat pada grafik di atas, menunjukkan nilai minimal sebesar 0,7 menurut 
parameter menunjukkan bashwa kerentanannya termasuk dalam kategori Tangguh, Kearifan Lokal dan Kepemimpinan memiliki kategori Tangguh sedangkan Kerentanan Sedang memiliki nilai minial sebesar 0,5 dan nilai yang lebih rendah dari itu memiliki Kerentanan Tinggi.

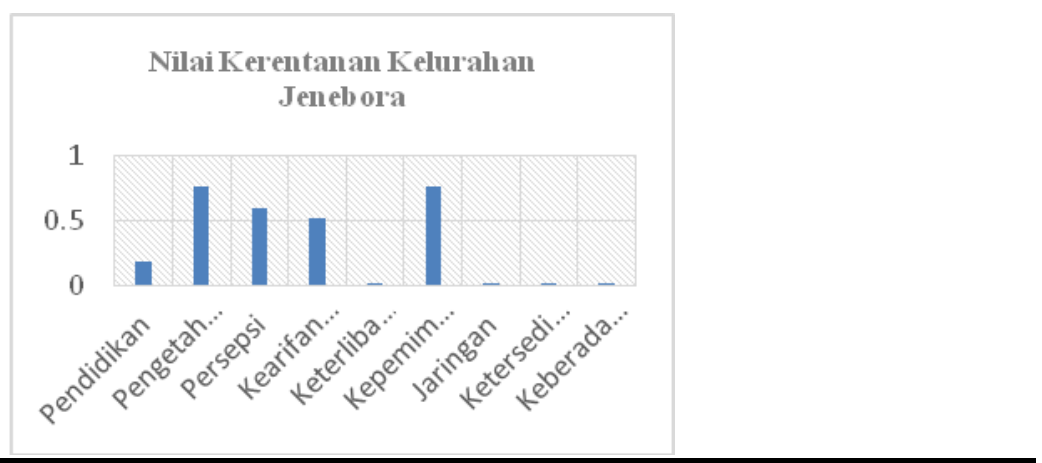

\section{Gambar 8. Grafik Nilai Kerentanan Kelurahan Jenebora}

Nilai kerentanan pada Kelurahan Jenebora dapat dilihat pada grafik di atas, menunjukkan nilai minimal sebesar 0,7 menurut parameter menunjukkan bahwa kerentanannya termasuk dalam kategori tangguh, Pengetahuan dan Kepemimpinan memiliki kategori Tangguh sedangkan Kerentanan Sedang memiliki nilai minial sebesar 0,5 dan nilai yang lebih rendah dari itu memiliki Kerentanan Tinggi.

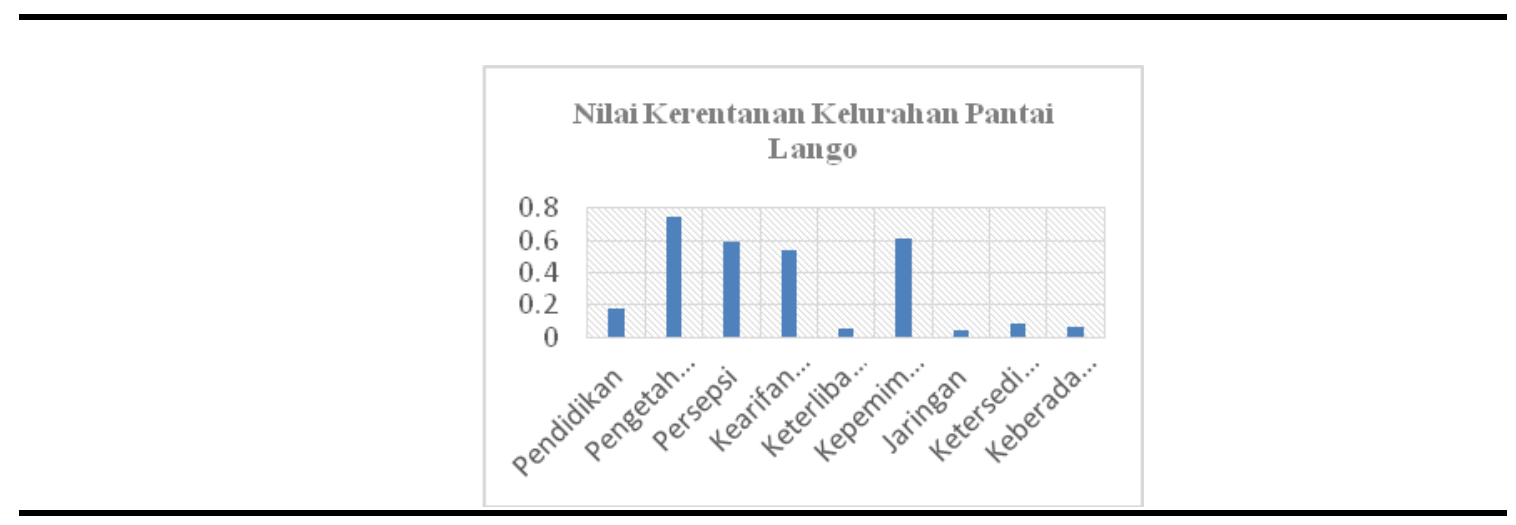

\section{Gambar 9. Grafik Nilai Kerentanan Kelurahan Pantai Lango}

Nilai kerentanan pada Kelurahan Pantai Lango dapat dilihat pada grafik di atas, menunjukkan nilai minimal sebesar 0,7 menurut parameter menunjukkan bahwa kerentanannya termasuk dalam kategori tangguh, pengetahuan adalah indikator yang memiliki kategori tangguh sedangkan kerentanan sedang memiliki nilai minial sebesar 0,5, dan nilai yang lebih rendah dari itu memiliki kerentanan tinggi.

\section{Perbandingan Kapasitas Adaptasi dari Tiga Kelurahan di Teluk Balikpapan}

Setelah mengetahui kerentanan pada masing indikator maka akan dilakukan perbandingan dari nilai rata-rata kapasitas adaptasi antara tiga kelurahan yang dihuni oleh masyarakat Bajo. Pada grafik di atas menunjukkan tingkat adaptasi yang paling tinggi 
adalah Kelurahan Penajam dengan nilai kerentanan 0,35 yang dalam parameter menunjukan bahwa Kelurahan Penajam memiliki kerentanan yang sedang. Untuk tingkat kemampuan adaptasi dua kelurahan lainnya, yaitu Kelurahan Jenebora dan Kelurahan Pantai Lango memiliki kemampuan adaptasi yang rendah/ lemah.

Tingkat kemampuan adaptasi masyarakat

bajo terhadap perubahan lingkungan di Teluk Balikpapan

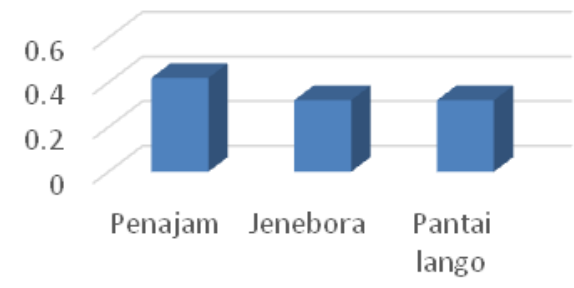

Gambar 10. Grafik Kerentanan Adaptasi Masyarakat Bajo Terhadap Perubahan Lingkungan

\section{KESIMPULAN}

Banyak fakta di lapangan yang menunjukkan terjadinya berbagai perubahan lingkungan di lokasi ini, yang kebanyakan bersifat negative (seperti pencemaran), baik dari aktivitas eksternal, maupun internal. Berbagai perubahan yang ada banyak memaksa warga Bajo beradaptasi, termasuk diantaranya merubah pola hidup, pola bermukim, dan bahkan bermata pencaharian.

Berdasarkan perbandingan kapasitas adaptasi, maka diketahui Kelurahan Penajam memiliki tingkat kerentanan sedang dengan nilai rata-rata kerentanan 0,42 sedangkan Kelurahan Jenebora dan Kelurahan Pantai Lango memiliki kerentanan yang tinggi dengan nilai yang sama persis yaitu 0,32. Angka ini bias menunjukkan bahwa Kelurahan Jenebora dan Kelurahan Pantai Lango masyarakatnya akan memiliki kesulitan dalam beradaptasi terhadap perubahan lingkungan yang memicu kerusakan lingkungan pesisir seperti kenaikan muka air laut, hilangnya tanaman bakau, perubahan garis pantai, pencemaran laut oleh sampah dan limbah serta eksploitasi dan eksplorasi yang terjadi terus menerus.

\section{DAFTAR PUSTAKA}

Aldon, E. T., Forbes, A. C., \& Ang, N. S. (2016). Sociocultural Factors Influencing Adaptation Capacity of Indigenous People in Barotac. Open Journal of Social Sciences, 4(January), 45-54.

AMAN. (2012). Republic of Indonesia, (October), 50119.

Apgar, M. J., Allen, W., Moore, K., \& Ataria, J. (2015). Understanding adaptation and transformation through indigenous practice: the case of the Guna of Panama. Ecology and Society, 20(1). https://doi.org/. http://dx.doi.org/10.5751/ES-07314-200145

Arikunto, S. (2002). Methode Penelitian. Jakarta: Rinneka Cipta.

Davidson, D. J. (2010). The applicability of the concept of resilience to social systems: Some sources of optimism and nagging doubts. Society and Natural Resources, 23(12), 1135-1149. https://doi.org/10.1080/08941921003652940

Egyir, I. S., Ofori, K., Antwi, G., \& Ntiamoa-baidu, Y. (2015). Adaptive Capacity and Coping Strategies in the Face of Climate Change: A Comparative Study of Communities around Two Protected Areas in the 
Coastal Savanna and Transitional Zones of Ghana. Journal of Sustainable Development, 8(1), 1-15. https://doi.org/10.5539/jsd.v8n1p1

Engle, N. L. (2011). Adaptive capacity and its assessment. Global Environmental Change, 21(2), 647-656. https://doi.org/10.1016/j.gloenvcha.2011.01.019

Ford, J. D., Berrang-ford, L., King, M., \& Furgal, C. (2010). Vulnerability of Aboriginal health systems in Canada to climate change. Global Environmental Change. https://doi.org/10.1016/j.gloenvcha.2010.05.003

Gudykunst,. Kim, \&. (2003). Communicating With Stranger. New York: McGraw Hill.

Gupta, J., Termeer, C., Klostermann, J., Meijerink, S., van den Brink, M., Jong, P., ... Bergsma, E. (2010). The Adaptive Capacity Wheel: A method to assess the inherent characteristics of institutions to enable the adaptive capacity of society. Environmental Science and Policy, 13(6), 459-471. https://doi.org/10.1016/j.envsci.2010.05.006

Heston, Y. P. (2014). Penyusunan Model Indeks Kapasitas Adaptasi Masyarakat Daerah Rentan Air Minum terkait Dampak Perubahan Iklim. https://www.researchgate.net/publication/273259925_PENYUSUNAN_MODEL_INDEKS_KAPASITA S_ADAPTASI_MASYARAKAT_DAERAH_RENTAN_AIR_MINUM_TERKAIT_DAMPAK_PERUBAHA N_IKLIM

Ilie, G. (2010). Application of Fishbone Diagram to Determine the Risk of an Event with Multiple Causes. Management Research and Practice, 2(1), 1-20.

Janssen, M. A., \& Ostrom, E. (2006). Resilience, vulnerability, and adaptation: A cross-cutting theme of the International Human Dimensions Programme on Global Environmental Change. Global Environmental Change, 16(3), 237-239. https://doi.org/10.1016/j.gloenvcha.2006.04.003

Klein, R. J. T., Nicholls, R. J., \& Thomalla, F. (2003). Resilience to natural hazards: How useful is this concept? Environmental Hazards, 5(1), 35-45. https://doi.org/10.1016/j.hazards.2004.02.001

Makkinuddin, N. (2010). Jembatan Pulau Balang: "Slilit" diantara Kaltim Hijau dan Janji Tuan Presiden. https://telukbalikpapan.wordpress.com/2010/05/06/jembatan-pulau-balang/

Nazir, M. (2005). Metode Penelitian. Jakarta: Ghalia.

Saturi, S. (2013). Teluk Balikpapan, dari Pembalakan sampai Penambangan Liar, 1. http://www.mongabay.co.id/2013/01/26/teluk-balikpapan-dari-pembalakan-liar-sampai-limbahtambang-batubara/

Spearman, M., \& McGray, H. (2011). Making Adaptation Count: Concepts and Options for Monitoring and Evaluation. Deutsche Gesellschaft fur. 